\title{
ECONOMIA SOLIDÁRIA COMO PROJETO CULTURAL E POLÍTICO: A EXPERIÊNCIA DO BANCO PALMAS, DE ANTONIO GEORGE LOPES PAULINO
}

\author{
Fernanda Rodrigues ${ }^{1}$
}

O livro "Economia Solidária como Projeto Cultural e Político: a experiência do Banco Palmas", é resultado de uma pesquisa realizada pelo Professor Antônio George Lopes Paulino no Conjunto Palmeiras, bairro localizado ao sul da cidade de Fortaleza, por ocasião do doutorado em sociologia no Programa de Pós - Graduação em Sociologia da Universidade Federal do Ceará, no período de 2003 a 2007.

A questão relevante e fundamental do livro consiste no recorte teórico metodológico que o autor realiza por meio de uma atualização acerca da temática da economia solidária. O autor afasta-se da análise assentada na economia solidária como uma alternativa ao capitalismo e opta por uma pesquisa etnográfica voltada à compreensão e interpretação da economia solidária como projeto político. Para tanto, o autor lança mão da teoria antropológica presente na obra de autores como Marcel Mauss, Victor Turner, Roberto DaMatta, Lea Rodrigues, Mariza Peirano, dentre outros.

O livro, prefaciado pela orientadora do autor, Elza Braga, éum convite a uma leitura instigante acerca da temática da economia solidária. $\mathrm{O}$ autor desenvolve nos seis capítulos sua questão central de investigação: interpretar a economia solidária como projeto político cultural e sua dimensão simbólica observada nas práticas

\footnotetext{
${ }^{1}$ Doutora em Sociologia e Consultora na área social.
} 
cotidianas. O autor escolheu como campo empírico a Associação de Moradores do Conjunto Palmeiras (ASMOCONP) e o Banco Palmas, escolhidos, conforme o autor, por serem emblemáticos à compreensão da experiência solidária desenvolvida ao longo dos últimos anos no Conjunto Palmeiras, e porque sedimentam os valores socioculturais em torno do bairro.

No primeiro capítulo, o autor nos mostra a construção e o desenvolvimento do percurso investigativo do seu trabalho: problematização do objeto, caminho metodológico, alcançado, segundo o autor, por um olhar etnográfico e uma perspectiva interpretativa.

No segundo capítulo, intitulado Um bairro, uma história: contexto local e gênese do Banco Palmas, o autor, por meio das falas das lideranças locais, apresenta ao leitor a história da construção do bairro Conjunto Palmeiras, iniciada na década de 1974, consequência de uma política de remanejamento levada a termo pela Prefeitura Municipal de Fortaleza. O autor ainda discute, nesse capítulo, questões urbanas relativas à cidade de Fortaleza, como, por exemplo, a especulação imobiliária, a organização dos moradores e os embates ocorridos no bairro do Conjunto Palmeiras em sua interface com os movimentos sociais.

No terceiro capítulo, Economia Solidária: significações históricas, teóricas e nativas, o autor nos atualiza com uma vasta digressão teórica acerca da construção da temática da economia solidária, que vai desde teóricos do socialismo utópico à literatura atual. A ideia é possibilitar ao leitor uma compreensão do processo de desenvolvimento de categorias e conceitos em torno da economia solidária. Assim, sem abandonar as representações relativas aos significados da economia solidária na perspectiva do morador, George nos apresenta uma vasta bibliografia sobre a temática da economia solidária, elucidando diversas abordagens teóricas acerca do tema.

"Aceitamos palmas": construção simbólica e prática da economia solidária no espaço local constitui o quarto capítulo. Nele, o autor apresenta de maneira substancial o trabalho etnográfico. Com rigor epistemológico, interpreta o significado 
conceitual da economia solidária a partir do cotidiano do Banco Palmas. Para tanto, o autor detém sua atenção sobre os eventos e cerimoniais realizados pelo sistema Banco Palmas /ASMOCONP, assim como volta seu olhar analítico para os símbolos em torno aos empreendimentos atrelados ao Banco palmas.

Destaco um dos trechos do livro que se encontra no quarto capítulo (p.233). Nele, o autor analisa o ambiente da associação de moradores, à época também sede do Banco Palmas, como um dos expoentes desse campo simbólico. Diz George, referindo-se ao salão principal da associação: "Assim, o ambiente interno (da ASMOCONP) parece assumir ares de um espaço sagrado", "um templo onde se reverencia a memória local", "a decoração da ASMOCONP parece configurá-lo quase como um santuário".

Desse modo, o autor nos mostra que o sistema ASMOCONP /BANCO PALMAS (expressão cunhada pelo autor) retratam simbolicamente a constituição do bairro do Conjunto palmeiras, seja por meios dos embates cotidianos observados nas falas e mensagens dos moradores presentes no decurso do livro, seja através das estratégias utilizadas pelas lideranças, e interpretadas pelo autor. É como se a história do bairro, contada pelas lideranças locais ao longo da construção do Conjunto Palmeiras, encontrasse no Banco Palmas e na ASMOCONP seus maiores expoentes.

Outro aspecto relevante tratado no livro é a articulação da temática da economia solidária no âmbito local e global, mostrando como estas duas dimensões se articulam tecendo uma rede de difusão e legitimidade do sistema Banco Palmas e ASMOCONP. É possível observar isto quando o autor descreve uma carreata por ocasião do lançamento da moeda social, o Palmas. Este cenário em que se misturam solenidade, festas e cerimoniais, é visto pelo autor como uma estratégia das lideranças locais para publicizar a ideia da solidariedade para dentro e fora do bairro.

No capítulo seguinte, Banco Palmas: as categorias público e privado na experiência local, o autor descreve as redes de solidariedades (relações de vizinhança, o sistema de microcrédito, a moeda social circulante, dentre outros) que permeiam o cotidiano do Conjunto Palmeiras, de forma que as fronteiras nas relações 
da vida privada e pública tornam-se quase imperceptíveis. O autor também realiza, nesse capítulo, uma leitura dos espaços interinstitucionais, atentando para a forma como estão inseridos neste contexto a ASMOCONP e o Banco Palmas.

O percurso investigativo escolhido pelo autor possibilita ao leitor observar, ao mesmo tempo, a dimensão comunitária e as tessituras da reciprocidade construídas nos diferentes momentos de estruturação dos empreendimentos no Conjunto Palmeiras e seus desdobramentos simbólicos dentro e fora da comunidade.

No sexto e último capítulo, Metáfora da rede: a economia solidária como movimento cultural e político, o autor avança na discussão realizada no capítulo anterior e analisa questões pertinentes à dimensão local e global na perspectiva dos movimentos sociais, assim como, também, as tensões presentes em torno da temática da economia solidária frente a sociedade em crise. Além do aporte teórico como ferramenta de compreensão em torno da temática acima, o autor considerou as percepções nativas acerca do alcance da economia solidaria.

A atenção à leitura interpretativa do autor torna possível vislumbrar, ainda, o modo como ocorrem as relações interinstitucionais, seja com as entidades da sociedade civil, seja com as instituições governamentais.

Esta perspicácia do autor torna o seu trabalho fundamental em se tratando dos estudos em torno da temática da economia solidária, e, nesse sentido, eu diria que seu livro torna-se uma fonte bibliográfica imprescindível à análise e compreensão da economia solidária, como uma ferramenta política cultural que opera tanto na perspectiva local como global.

Por fim, o livro, para além de ser uma obra inédita, em se tratando do sistema Banco Palmas/ASMOCONP, é um trabalho de fôlego e extremamente bem escrito, e traz tanto para a sociologia como para a antropologia aportes teóricos, lentes interpretativas de um fenômeno social, como bem dito pelo autor, em gestação. 